\title{
Anaesthetic technique does not influence postoperative bowel function: a comparison of propofol, nitrous oxide and isoflurane
}

The aim of this study was to evaluate the influence of propofol, nitrous oxide and isoflurane on recovery, postoperative bowel function and postoperative complications after major gastrointestinal surgery. Sixty patients undergoing elective colonic operations were included in the study. They were randomly allocated to anaesthesia with isoflurane-nitrous oxide, propofolair, or propofol-nitrous oxide, with fentanyl and vecuronium being used in all three groups. The same anaesthetic and surgical teams performed all the operations. The postoperative course was judged once each day by the Acute Physiology Score (APS) based on the Apache II classification, passage of gas, tolerance of enteral feeding, hospital stay and complications up to 30 days after surgery. The demographic data, magnitude of operation, duration of operation, intraoperative blood loss, and post-operative analgesic needs were similar in the groups. In all groups the APS was normal by median day 1 (range 1-7). A similar impairment of bowel function after operation, with passage of gas median $3(1-6)$ days after surgery and tolerance

\section{Key words}

ANAESTHETICS, INTRAVENOUS: fentanyl, propofol; ANAESTHETICS, VOLATILE: isoflurane, nitrous oxide; RECOVERY ASSESSMENT: acute physiology score, bowel function, complications;

SURGERY: abdominal.

From the Departments of Anaesthesiology* and Surgeryt, Faculty of Health Sciences, University Hospital Linköping, S-581 85 Linköping, Sweden.

The study was presented in parts at the 21 st Congress of The Scandinavian Society of Anaesthesiologists, Trondheim, Norway, June 1991.

Address correspondence to: Dr. A.G. Jensen, Department of Anaesthesiology, Faculty of Health Sciences, University Hospital Linköping, S-581 85 Linköping, Sweden.

Accepted for publication 28th June, 1992.
Anders G. Jensen MD DEAA, ${ }^{*}$ Sigga H. Kalman MD, * Per-Olof Nyström MD PhD, $\dagger$ Christina Eintrei MD PhD* of enteral intake median day 5(1-10), was found in all groups. The incidence of complications and the length of postoperative hospital stay, median 11 (6-45) days, did not differ among the groups. It is concluded that overall recovery, bo:vel function. postoperative hospital stay, and complications were not influenced by the anaesthetic technique.

L'objectif de cette étude est d'évaluer l'influence du propofol, du protoxyde d'azote et de l'isoflurane sur la rétablissement. l'activité intestinale et les complications après une chirurgie gastro-intestinale majeure. L'étude inclut soixante patients subissant une intervention non urgente sur le colon. Ils sont distribués de façon aléatoire en trois groupes: isoflurane. protoxyde, propofol-air, propofol-protoxyde. Pour supplémenter, les trois groupes reçoivent du fentanyl et du vécuronium. Un seul anesthésiste et une seule équipe chirurgicale réalisent troutes les interventions. L'évolution postopératoire est cotée quotidiennement sur l'échelle physiologique APS dérivée de la classification Apache II, sur le passage de gaz, la tolérance de l'alimentation orale, la durée du séjour hospitalier et les complications postopératoires apparaissant avant 30 jours. Les données démographiques, la durée de l'intervention, les pertes sanguines peropératoires et les besoins analgésiques postopératoires sont indentiques pour tous les groupes. Les résultats montrent que pour chacun des groupes, l'échelle APS se normalise entre 1 et 7 jours (médiane 1). La dysfunction intestinale est aussi la même après l'opération alors que le passage des gaz reprend entre 1 et 6 jours (médiane 3) et le retour à l'alimentation orale entre 1 et 10 jours (médiane 5). L'incidence des complications et la durée du séjours postopératoire (6-45 jours: médiane 11) sont identiques pour les trois groups. On peut conclure que la récupération, la fonction intestinale et l'incidence des complications ne subissent pas l'influence de la technique anesthésique.

The gastro-intestinal tract is now recognised as a metabolically and physiologically active and sensitive 
TABLE I Guidelines for anaesthetic drugs in the three groups. The doses could be changed based on defined clinical signs of inadequate anaesthesia.

\begin{tabular}{llll}
\hline & Isoflurane $\mathrm{N}_{2} \mathrm{O}$ & Propofolair & Propofol/ $\mathrm{N}_{2} \mathrm{O}$ \\
\hline Ventilation & Isoflurane, $\mathrm{N}_{2} \mathrm{O} / \mathrm{O}_{2}$ & $\mathrm{O}_{2}$ /air & $\mathrm{N}_{2} \mathrm{O} / \mathrm{O}_{2}$ \\
Anaesthetic & Thiopentone & Propofol & Propofol \\
Induction & $4 \mathrm{mg} \cdot \mathrm{kg}^{-1}$ & $2 \mathrm{mg} \cdot \mathrm{kg}^{-1}$ & $2 \mathrm{mg} \cdot \mathrm{kg}^{-1}$ \\
Infusion & & $9 \mathrm{mg} \cdot \mathrm{kg}^{-1} \cdot \mathrm{hr}^{-1}$ & $6 \mathrm{mg} \cdot \mathrm{kg}^{-1} \cdot \mathrm{hr}^{-1}$ \\
Infusion after $30 \mathrm{~min}$ & & $6 \mathrm{mg} \cdot \mathrm{kg}^{-1} \cdot \mathrm{hr}^{-1}$ & $4 \mathrm{mg} \cdot \mathrm{kg}^{-1} \cdot \mathrm{hr}^{-1}$ \\
& & & \\
Opioid & $\mathrm{Fentanyl}$ & $\mathrm{Fentanyl}$ & $\mathrm{Fentanyl}$ \\
Induction & $2 \mu \mathrm{g} \cdot \mathrm{kg}^{-1}$ & $2 \mu \mathrm{g} \cdot \mathrm{kg}^{-1}$ & $2 \mu \mathrm{g} \cdot \mathrm{kg}^{-1}$ \\
Infusion/bolus & $2 \mu \mathrm{g} \cdot \mathrm{kg}^{-1}$ & $7.5 \mu \mathrm{g} \cdot \mathrm{kg}^{-1} \cdot \mathrm{hr}^{-1}$ & $5 \mu \mathrm{g} \cdot \mathrm{kg}^{-1} \cdot \mathrm{hr}^{-1}$ \\
After 30 min & $2 \mu \mathrm{gg} \cdot \mathrm{kg}^{-1}$ & $3.75 \mu \mathrm{g} \cdot \mathrm{kg}^{-1} \cdot \mathrm{hr}^{-1}$ & $2.5 \mu \mathrm{g} \cdot \mathrm{kg}^{-1} \cdot \mathrm{hr}^{-1}$ \\
\hline
\end{tabular}

organ. ${ }^{1}$ Anaesthetic drugs may contribute to morbidity after gastro-intestinal operations by influencing gut physiology. ${ }^{2}$ The effects could be mediated through drug action on the cardiovascular system leading to diminished perfusion and oxygen delivery to the viscera, or by impairing the motor activity of the intestine. ${ }^{2}$ This could lead to paralytic ileus, bacterial overgrowth, loss of the intestinal barrier, and translocation of endotoxins and bacteria. ${ }^{3.4}$ Transient paralysis of the intestines is a predominant component of the post-surgical stress response. ${ }^{5}$ It is, therefore, important to design anaesthetic methods that do not interfere with recovery of intestinal function.

Nitrous oxide diffuses from blood into air-containing body cavities more rapidly than nitrogen diffuses out. Gas volume in the intestinal lumen has been found to increase after nitrous oxide administration in dogs, ${ }^{6}$ and nitrous oxide has also been shown to delay bowel function after elective colonic operations ${ }^{7}$ in humans. Thiopentone increases motor activity in the colonic wall ${ }^{8}$ whereas ketamine has no such effect. ${ }^{9}$ Propofol has no effect on gastrointestinal activity, compared with the slightly prolonged transit time after thiopentone, in mice. ${ }^{10}$ Isoflurane reduces arterial blood pressure which may be expected to impair intestinal perfusion. It has been shown, however, in animal studies, ${ }^{11}$ that isoflurane increases intestinal blood flow despite a decrease in mean arterial pressure.

We performed this study because propofol and isoflurane are considered to have minimal influence on bowel function after surgery, while nitrous oxide has been shown to impair bowel function. ${ }^{7}$ We compared the affects of propofol with and without nitrous oxide, with isot.uranenitrous oxide anaesthesia on recovery, postoperative bowel function, complications, and length of hospital stay, in patients undergoing colorectal operations.

\section{Methods}

The study was performed in accordance with the Helsinki II Declaration and was approved by the Human Ethics
Committee of the University Hospital in Linköping. Sixty patients, age 18 to $85 \mathrm{yr}$, scheduled for intraabdominal operations of the colon and rectum gave informed consent to participate in the study. They were randomised blindly to one of three anaesthetic methods, using a set of numbered envelopes.

\section{Anaesthetic management}

For premedication all patients were given flunitrazepam 0.5 to $1 \mathrm{mg}$ po one hour before the expected start of anaesthesia. After induction of anaesthesia, tracheal intubation was facilitated by succinylcholine $1 \mathrm{mg} \cdot \mathrm{kg}^{-1}$ iv. Vecuronium was used to maintain relaxation which was assessed using a peripheral nerve stimulator, aiming for the return of at least two twitches in response to train-offour stimulation, before giving the next dose.

Patients allocated to Group 1 received thiopentone 4 $\mathrm{mg} \cdot \mathrm{kg}^{-1}$ and fentanyl $2 \mu \mathrm{g} \cdot \mathrm{kg}^{-1}$ iv for induction of anaesthesia (Table I). Additional thiopentone was given if needed. During the operation the lungs were ventilated with isoflurane and $30 \%$ oxygen in nitrous oxide. Fentanyl $i v$ was added in amounts to ensure adequate anaesthesia. Patients in Group 2 received total iv anaesthesia ${ }^{12}$ (Table I), with sleep induction by propofol $2 \mathrm{mg} \cdot \mathrm{kg}^{-1}$ followed immediately by an initial infusion of $9 \mathrm{mg} \cdot \mathrm{kg}^{-1} \cdot \mathrm{hr}^{-1}$ of propofol, reduced to $6 \mathrm{mg} \cdot \mathrm{kg}^{-1} \cdot \mathrm{hr}^{-1}$ after $30 \mathrm{~min}$. Fentanyl was given in a bolus dose of $2 \mu \mathrm{g} \cdot \mathrm{kg}^{-1}$, followed by an infusion of $7.5 \mu \mathrm{g} \cdot \mathrm{kg}^{-1} \cdot \mathrm{hr}^{-1}$. The rate of fentanyl infusion was reduced after $30 \mathrm{~min}$ to $3.75 \mu \mathrm{g} \cdot \mathrm{kg}^{-1} \cdot \mathrm{hr}^{-1}$. Ventilation was with oxygen in air to give an inspiratory fraction of oxygen of 0.3 . For patients in Group 3 a modified iv technique was used (Table I). Propofol $2 \mathrm{mg} \cdot \mathrm{kg}^{-1}$ iv was given for induction of sleep and an infusion of propofol was given at a rate of $6 \mathrm{mg} \cdot \mathrm{kg}^{-1} \cdot \mathrm{hr}^{-1}$ for the first $30 \mathrm{~min}$ and then reduced to $4 \mathrm{mg} \cdot \mathrm{kg}^{-1} \cdot \mathrm{hr}^{-1}$. Fentanyl was given for induction in a bolus dose of $2 \mu \mathrm{g} \cdot \mathrm{kg}^{-1}$, followed by an infusion of $5 \mu \mathrm{g} \cdot \mathrm{kg}^{-1} \cdot \mathrm{hr}^{-1}$. After $30 \mathrm{~min}$, this infusion rate was reduced to $2.5 \mu \mathrm{g} \cdot \mathrm{kg}^{-1} \cdot \mathrm{hr}^{-1}$. During anaesthesia 
the lungs of these patents were ventilated with $30 \%$ oxygen in nitrous oxide.

Whenever needed, the infusion rates of both propofol and fentanyl (Groups 2 and 3 ) or the inhaled concentration of isoflurane (Group 1), were changed based on the use of precisely defined clinical signs of inadequate anaesthesia. ${ }^{13}$ The following clinical criteria were used to increase the depth of anaesthesia: increase of systemic arterial systolic pressure greater than $15 \mathrm{mmHg}$ above preoperative pressure, a heart rate exceeding $90 \mathrm{bpm}$ in the absence of hypovolaemia, somatic responses including bodily movements, swallowing, coughing, grimmacing, or eye opening and other autonomic signs of inadequate anaesthesia, such as lacrimation, flushing, or sweating.

The lungs were ventilated with warm, humidified gases. Ventilaton was adjusted to give an arterial carbon dioxide pressure $\left(\mathrm{PaCO}_{2}\right)$ of 4-4.5 kPa. For blood pressure monitoring and blood sampling all patients had an arterial catheter placed before induction of anaesthesia, and a central catheter was inserted to measure central venous pressure. Central venous pressure was held constant at about $10 \mathrm{mmHg}$, and a urine output of more than 50 $\mathrm{ml} \cdot \mathrm{hr}^{-1}$ was obtained by the infusion of crystalloids. Perand postoperatve transfusion of red blood cells and plasma was considered at a haemoglobin concentration of 90 $\mathrm{g} \cdot \mathrm{L}^{-1}$, if the circulaton was unstable. Only $15 \%$ of the patients were transfused. A pulse oximeter was used during anaesthesia, and monitoring data were collected continuously by a computer (Hewlett-Packard 54S).

One hour before the expected end of surgery the fentanyl infusion was discontinued. The propofol infusion and the inhalaton of isoflurane were terminated at the first skin suture. Muscle relaxation was reversed with glycopyrrolate $0.5 \mathrm{mg}$ and neostigmine $2.5 \mathrm{mg}$ iv and naloxone $0.02 \mathrm{mg}$ was given if respiratory frequency was < ten breaths per min. After reversal, the lungs of all patients were ventilated with $100 \%$ oxygen, and the tracheas were extubated in the operating theatre. For postoperative pain relief in the first $24 \mathrm{hr}$ ketobemidone (opioid, equianalgesic to morphine) $2.5 \mathrm{mg}$ was given $i v$ on the patient's request. Thereafter, meperidine $50 \mathrm{mg} \mathrm{im}$ was used as well as ketobemidone $5 \mathrm{mg}$ im for pain relief.
TABLE II Seven variables forming the operation score. The surgeon graded each variable from simple to difficult by analogue technique. A score of zero was given for the normal procedure, one was assigned for estimates between the 51-75 percentile and two points for a score above the $76 \%$ percentile. Maximum score was 14 .

Ease of exposure

Disturbing bleeding

Ease of dissection

Ease of reconstruction

Demand on judgment

Demand on technical skill

Psychological stress

\section{Surgical management}

To document the magnitude of the operations allocated to each group, two measures were used, according to the tradition in this department. Before operation, procedures were graded from 1-4 by the anticipated magnitude of dissection. Grade 1 procedures were minor. Grade 2 procedures were all resections of segments of the colon. Grade 3 procedures were either total colectomy, or low resections of the rectum. Grade 4 procedures were abdominoperineal amputation of the rectum, or restorative proctectomy for ulcerative colitis. During the operation, the surgeon evaluated the difficulty of the pathology and components of the surgical work by rating each of seven variables by an analogue technique (Table II). For each operation, a summary score (0-14 points) was achieved.

The patient's postoperative course was judged once each day. The first day that a patient fulfilled the criteria was recorded. The variables were the 12 individual variable points of the Acute Physiology Score (APS) from the Apache classification ${ }^{14}$ including temperature, restored intestinal motor function with passage of gas or ileostomy producing more than $100 \mathrm{ml}$ per day, and tolerance of enteral feeding of more than $1000 \mathrm{ml}$ per day (Table III). Two of the 12 variables from the APS were allowed to be out of the normal range. All complications up to 30 days after surgery were recorded.

The surgical team members, who were uninformed about the treatment allocation, made all of the above

TABLE III The four physiological variables used to judge recovery, and postoperative stay in hospital. All data are in days, and given as median and ( $\min$-max). There were no statistical differences among the groups.

\begin{tabular}{|c|c|c|c|}
\hline & Isoflurane/ $\mathrm{N}_{2} \mathrm{O}$ & Propofollair & Propofoll $\mathrm{N}_{2} \mathrm{O}$ \\
\hline Acute Physiology Score $\leq 2$ & $1(1-3)$ & $1(1-7)$ & $1(1-2)$ \\
\hline $\begin{array}{l}\text { Temperature }<37.8^{\circ} \mathrm{C} \\
\text { for } 24 \text { hours }\end{array}$ & $2(1-7)$ & $1(1-7)$ & $1(1-3)$ \\
\hline Passage of gas, & & & \\
\hline $\begin{array}{l}\text { or ileostomy producing } \geq 100 \mathrm{ml} \\
\text { Oral intake } \geq 1000 \mathrm{ml}\end{array}$ & $\begin{array}{l}3(2-5) \\
5(2-9)\end{array}$ & $\begin{array}{l}3(2-7) \\
5(2-8)\end{array}$ & $\begin{array}{l}3(2-5) \\
5(1-10)\end{array}$ \\
\hline Postoperative hospital stay & $13(8-22)$ & $11(6-45)$ & $11(6-37)$ \\
\hline
\end{tabular}


TABLE IV Demographic data of the patients. Values for age, weight and height are given as mean (standard deviation), sex and type of disease as ratio. There were no differences among the groups.

\begin{tabular}{llll}
\hline & Isoflurane $\mathrm{N}_{2} \mathrm{O}$ & Propofolair & Propofol/ $\mathrm{N}_{2} \mathrm{O}$ \\
\hline Age, yr & $52(18)$ & $60(19)$ & $55(17)$ \\
Weight, kg & $67(12)$ & $67(12)$ & $70(9)$ \\
Height, cm & $170(8)$ & $166(10)$ & $171(9)$ \\
Sex, male/female & $13 / 7$ & $11 / 9$ & $10 / 10$ \\
Malign/benign & $8 / 12$ & $12 / 8$ & $13 / 7$ \\
\hline
\end{tabular}

TABLE V Comparison of anaesthesia and operation characteristics All data are given as median and $(\min -\max )$. There were no differences among the groups.

\begin{tabular}{llll}
\hline & Isoflurane $\mathrm{N}_{2} \mathrm{O}$ & Propofollair & Propofol/ ${ }_{2} \mathrm{O}$ \\
\hline Anaesthesia time & 250 & 278 & 263 \\
(min) & $(155-515)$ & $(95-457)$ & $(100-425)$ \\
Operation time & 200 & 225 & 209 \\
(min) & $(110-440)$ & $(61-355)$ & $(55-355)$ \\
Bleeding & 500 & 375 & 350 \\
(ml) & $(100-4000)$ & $(50-1000)$ & $(50-1450)$ \\
Magnitude & 3 & 3 & 3 \\
(arbitrary units) & $(2-4)$ & $(2-4)$ & $(1-4)$ \\
Operation score & 2 & 0 & 2 \\
(arbitrary units) & $(0-7)$ & $(0-6)$ & $(1-5)$ \\
\hline
\end{tabular}

observations which were only provided to the anaesthetic team members for the final evaluation of the results.

\section{Statistics}

All quantitative data were displayed as percentile distributions to study homogeneity in each group. Differences between distributions were tested with the Mann-Whitney $U$ test. The Kruskal-Wallis one-way analysis of variance by ranks was used for categorical data. The chi-squared test was used for comparison of complications. The level of statistical significance was set at $P<0.05$. A statistical power analysis was performed to determine the probability of a type II (or $\beta$ ) error.

\section{Results}

All 60 patients fulfilled the protocol requirements, and no data were excluded. The groups were well balanced with respect to age, sex, weight, height, and type of disease (Table IV). The duration of anaesthesia, duration of operation, perioperative bleeding, magnitude of surgery and operation scores were statistically the same in all three groups (Table V). Ventilation and oxygenation as well as acid-base variables were the same in all groups during the operation and for the following three days. ${ }^{15}$ The magnitude of surgery correlated $(P<0.01)$ with intraoperative bleeding, operation time and length of hospital stay. The amount of fentanyl given in the propofol/air group was
TABLE VI Analgesic requirements. Amount of fentanyl during the operation and ketobemidone $(K)$ and meperidine $(M)$ on the day of operation and on days 1 to $3 . \mathrm{K} / \mathrm{M}$ is the number of patients receiving ketobemidone and meperidine respectively. The values are given as mean (standard deviation). The dose of fentanyl was higher in the propofol/air group than in the other two groups $(P<0.05)$. Otherwise, there were no differences among the groups.

\begin{tabular}{clll}
\hline & $\begin{array}{l}\text { Isofluranel } \\
\mathrm{N}_{2} \mathrm{O}\end{array}$ & $\begin{array}{l}\text { Propofol } \\
\text { air }\end{array}$ & $\begin{array}{l}\text { Propofol } \\
\mathrm{N}_{2} \mathrm{O}\end{array}$ \\
\hline $\begin{array}{clll}\text { Fentanyl } \\
\left(\mu \mathrm{g} \cdot \mathrm{kg}^{-1} \cdot \mathrm{hr}^{-1}\right)\end{array}$ & $2,5(0,5)$ & $4,3(1,2)$ & $3,3(0,9)$ \\
Day of operation & & & \\
$\mathrm{K}(\mathrm{mg})$ & $12(7)$ & $8(4)$ & $15(11)$ \\
Day $1 \mathrm{~K}(\mathrm{mg})$ & $15(8)$ & $11(7)$ & $12(9)$ \\
$\mathrm{M}(\mathrm{mg})$ & $230(110)$ & $160(80)$ & $160(125)$ \\
$\mathrm{K} / \mathrm{M}$ & $12 / 7$ & $12 / 7$ & $13 / 7$ \\
& & $13(8)$ & $18(6)$ \\
Day $2 \mathrm{~K}(\mathrm{mg})$ & $16(10)$ & $217(130)$ & $90(100)$ \\
$\mathrm{M}(\mathrm{mg})$ & $196(145)$ & $10 / 7$ & $12 / 2$ \\
$\mathrm{~K} / \mathrm{M}$ & $12 / 5$ & $11(4)$ & $12(8)$ \\
& & $167(150)$ & $84(75)$ \\
Day $3 \mathrm{~K}(\mathrm{mg})$ & $12(6)$ & $8 / 6$ & $12 / 2$ \\
$\mathrm{M}(\mathrm{mg})$ & $145(160)$ & & \\
$\mathrm{K} / \mathrm{M}$ & $6 / 6$ & & \\
\hline
\end{tabular}

higher than in the two other groups $(P<0.05)$ (Table VI). Equal amounts of ketobemidone or meperidine were given in all three groups for the treatment of postoperative pain (Table VI).

For all groups, the time to achieve a normal physiology score (APS), passage of flatus or tolerance of oral intake of more than $1000 \mathrm{ml}$ per day of fluid was similar as was the length of postoperative hospital stay (Table III).

Post-surgical complications were equally common in all groups (Table VII). One patient from each group had a postoperative abscess, which was treated with percutaneous or transanal drainage. Two improved rapidly but one patient (from the propofol/air group) developed fungal septicaemia, and was in hospital for $\mathbf{4 5}$ days. One patient from the propofol $/ \mathrm{N}_{2} \mathrm{O}$ group had an anastomotic breakdown and was reoperated upon, leading to a hospital stay of 29 days. Pulmonary atelectasis ${ }^{15}$ was noted in two patients, one from the isoflurane $/ \mathrm{N}_{2} \mathrm{O}$ group and one from the propofol/air group; both patients improved after physiotherapy, bronchoscopy and antibiotics.

\section{Discussion}

The major finding in this study was the minimal influence of the anaesthetic technique on the postoperative course. This result is contrary to a recent article, ${ }^{7}$ in which nitrous oxide was shown to delay return of normal bowel function after colonic surgery. The type of surgery, number of patients, length of operation and duration of anaesthesia in 
TABLE VII Postsurgical complications. There were no differences among the groups.

\begin{tabular}{lll}
\hline Isoflurane/ $\mathrm{N}_{2} \mathrm{O}$ & Propofollair & Propofol/ $\mathrm{N}_{2} \mathrm{O}$ \\
\hline Ileal pouch fistula & Abscess, fungicaemia & Abscess \\
Stoma infection & iv line bacteraemia & Anastomotic dehiscence \\
Gastric retention & Pneumonia & Cl. difficile colitis \\
Transient ileus & UT infection & \\
Pulmonary atelectasis & Pulmonary atelectasis & \\
Anastomotic bleed & & \\
\hline
\end{tabular}

that study were comparable to those in our study. One difference was that they injected $200 \mathrm{ml}$ of air into the stomach to standardize the amount of preoperative gastric gas content. ${ }^{7}$ This procedure could have caused adverse effects due to diffusion of nitrous oxide into the gas-filled cavities. Otherwise it is difficult to explain the contrary results.

We chose a study design in which the anaesthesia and the operation were performed, and the patient outcome recorded, by the anaesthetic and the surgical teams blinded to each other's results until completion of the trial. This design allowed a high degree of objectivity. We used objective measures to describe the operations and postsurgical recovery. The groups were similar in all respects. The choice of standard inhalational anaesthesia versus intravenous anaesthesia (isoflurane $/ \mathrm{N}_{2} \mathrm{O}$ versus propofol air), or an intravenous based anaesthesia with or without nitrous oxide (propofol/air versus propofol $\mathrm{N}_{2} \mathrm{O}$ ) did not affect the results.

Anaesthetic drugs are associated with changed bowel function after abdominal operations. Thiopentone has been shown to increase motor activity in the duodenum and jejunum in an animal model. ${ }^{8}$ Two other intravenous agents, propofol ${ }^{10}$ and ketamine, ${ }^{9}$ have not been reported to have such effects.

Decreased blood flow and oxygen supply to the colon may influence anastomotic healing. ${ }^{16}$ Cardiac output and tissue perfusion pressure are variables that may be influenced by the anaesthetic method. Intravenous induction agents decrease regional blood flow by decreasing myocardial contractility and by producing peripheral vasodilatation. ${ }^{17}$ However, isoflurane is known to increase intestinal blood flow in animals despite a decrease in mean arterial pressure." In our study, clinically defined variables ${ }^{13}$ were used during the operation to monitor and maintain blood pressure, heart rate, and depth of anaesthesia constant.

All patients were anaesthetized with the addition of fentanyl at a rate per $\mathrm{kg} \cdot \mathrm{hr}{ }^{-1}$ that differed among the groups. The amount was higher when nitrous oxide was absent. The aim was to give adequate anaesthesia based on the clinical signs and therefore the doses were not standardized among groups. The doses of fentanyl for the propofol/air group were taken from previously published studies. ${ }^{12}$ The doses of fentanyl in the isoflurane/nitrous oxide group were those ordinarily used in our department, and the doses of both fentanyl and propofol were reduced in the group with propofol/nitrous oxide to allow for the effects of nitrous oxide. ${ }^{18}$ The similarity in haemodynamic responses (unpublished observations) indicated that the anaesthetic depth was similar in all three groups. Highdose fentanyl anaesthesia $\left(56.3 \mu \mathrm{g} \cdot \mathrm{kg}^{-1}\right)$ delays recovery of bowel motility. ${ }^{19}$ This effect is higly dose-dependent, ${ }^{19}$ and, since the doses used in this study were far below the doses in that study, we do not think that the amount of fentanyl had any influence on the results. Alfentanil, a short-acting opioid, ${ }^{20}$ might have been a better choice than fentanyl. The two drugs have approximately the same distribution half-lives but the terminal half-life of alfentanil is about half that of fentanyl. ${ }^{20}$ Seven of 20 patients in the propofol/air group received naloxone to reverse fentanyl depression of respiration, and this might not have been necessary if we had used the shorter-acting alfentanil.

Postoperative opiates have variable effects on bowel motility. Morphine diminishes propulsive peristaltic waves in the colon and increases tone. ${ }^{21}$ Meperidine does not produce these effects and could be a safer analgesic for patients who have operations with an anastomosis. ${ }^{22}$ The specific pattern of motility in the gut after ketobemidone has not been described. The amount of ketobemidone or meperidine for postoperative analgesia was similar in the study groups and could not have influenced the results.

Neostigmine, used to antagonize neuromuscular blockade, has major effects on the bowel. Intraluminal pressure and colonic and rectal motor activity are increased, ${ }^{23}$ and mesenteric blood flow is reduced by up to $50 \%$ after clinical doses, the reduction being associated with the increased activity, and partly antagonized by atropine. ${ }^{24}$ All our patients were given neostigmine and glycopyrrolate in similar amounts, producing an equal influence of this factor in each group.

To determine the probability of a type II error we performed power analysis on the variables that were considered to be the most important: hospital stay, enteral feeding and passage of gas. We wanted to be able to detect a difference that was at least $25 \%$, that is four days 
difference in hospital stay, two days difference in enteral feeding and one day difference in passage of gas. The power could be calculated to $0.85,0.95$ and 0.91 respectively, and this suggested that the number of subjects was adequate to determine with an $85 \%$ certainty if differences existed. Therefore, we consider our results to be valid.

We conclude that anaesthesia with or without nitrous oxide, or anaesthesia based on isoflurane or propofol, results in similar postoperative recovery, the same impairment of bowel function, and an equal incidence of postsurgical complications.

\section{References}

1 Wilmore DV, Smith RJ, O'Dwyer ST, Jacobs DO, Ziegler $T R$, Wang $X-D$. The gut: a central organ after surgical sress. Surgery 1988; 104: 917-23.

2 Aitkenhead $A R$. Anaesthesia and the gastro-intestinal system. Eur J Anaesthesiol 1988; 5: 73-112.

3 Deitch EA. Simple intestinal obstruction causes bacterial translocation in man. Arch Surg 1989; 124: 699-701.

4 Deitch $E A$. The role of intestinal barrier failure and bacterial translocation in the development of systemic infection and multiple organ failure. Arch Surg 1990; 125: 403-4.

5 Kehlet $H$. Surgical stess: the role of pain and analgesia. $\mathrm{Br}$ J Anaesth 1989; 63: 189-95.

6 Eger EI, Saidman $W$. Hazards of nitrous oxide anesthesia in bowel obstruction and pneumothorax. Anesthesiology $1965 ; 26: 61-6$.

7 Scheinin B, Lindgren L, Scheinin TM. Peroperative nitrous oxide delays bowel function after colonic surgery. Br J Anaesth 1990; 64: 154-8.

8 Healy TEJ, Foster GE, Evans DF, Syed A. Effect of some i.v. anaesthetic agents on canine gastrointestinal motility. Br J Anaesth 1981; 53: 229-33.

9 Grant IS, Nimmo WS, Clements JA. Lack of effect of ketamine analgesia on gastric emptying in man. $\mathrm{Br} \mathrm{J}$ Anaesth 1981; 53: 1321-3.

10 Glen $J B$, Hunter $S C$, Blackburn TP, Wood P. Interaction studies and other investigations of the pharmacology of propofol ("Diprivan"). Postgrad Med J 1985; 61 (suppl.3): $7-14$.

11 Ostman M, Biber B, Martner J, Reiz S. Influence of isoflurane on renal and intestinal vascular responses to stress. Br J Anaesth 1986; 58: 630-8.

12 De Grood PMRM, Ruys AHC, van Egmond J, Booij LHDJ, Crul JF. Propofol ("Diprivan") emulsion for total intravenous anaesthesia. Postgrad Med J 1985; 61 (suppl 3): 65-9.

13 Ausems ME, Vuyk J, Hug CC, Stanski DR. Comparison of a computer-assisted infusion versus intermittent bolus administration of alfentanil as a supplement to nitrous oxide for lower abdominal surgery. Anesthesiology 1988; 68: 851-61.
14 Knaus WA, Draper EA, Wagner DP, Zimmerman JE. Apache 11: a severity of disease classification system. Crit Care Med 1985; 13: 818-29.

15 Jensen AG, Kalman SH, Fransson S-G, Morales $O$, Eintrei $C$. Atelectasis and oxygenation in major surgery, propofol with or without nitrous oxide versus isoflurane based anaesthesia for intestinal surgery. Anaesthesia (accepted for publication).

16 Shandall A, Lowndes $R$, Young $H L$. Colonic anastomotic healing and oxygen tension. Br J Surg 1985; 72: 606-9.

17 Sear JW. Toxicity of i.v. anaesthetics. Br J Anaesth 1987; 59: 24-45.

18 Coates DP, Monk CR, Prys-Roberts C, Turtle M. Hemodynamic effects of infusion of the emulsion formulation of propofol during nitrous oxide anesthesia in humans. Anesth Analg 1987; 66: 64-70.

19 Yukioka $H$, Tanaka M, Fujimori $M$. Recovery of bowel motility after high dose fentanyl or morphine anaesthesia for cardiac surgery. Anaesthesia 1990; 45: 353-6.

20 Bovill JG, Sebel PS, Blackburn CL, Heykants J. The pharmacokinetics of alfentanil (R 39 209): a new opioid analgesic. Anesthesiology 1982; 57: 439-43.

21 Jaff $J H$, Martin WR. Opioid analgesics and antagonists. In: Gilman AG, Goodman LS, Rall TW, Murad F (Eds.). The Pharmacological Basis of Therapeutics. 7th ed. New York: Macmillan publishing, 1985; 491-531.

22 Aitkenhead AR. Complications following large-bowel surgery. Reg Anesth 1982; 4 (Supp1. 7): S99-S104.

23 Wilkins JL, Hardcastle JD, Mann CV, Kaufmann L. Effects of neostigmine and atropine on motor activity of ileum, colon, and rectum of anaesthetized subjects. BMJ 1970; $1: 793-4$.

24 Whitaker $B L$. Observations on the blood flow in the inferior mesenteric arterial system and the healing of colonic anastomoses. Ann R Coll Surg Eng 1968; 43: 89-110. 